\title{
116. Molecular Cloning of a Complementary DNA of Phenobarbital-Inducible Cytochrome P.450 Messenger RNA from the Rat
}

\author{
By Yoshiaki FujiI-Kuriyama,*) Tadatsugu TaniguchI,*) \\ Yuzuru Mizukami,*) Masaharu SAKaI,*) \\ Yutaka TASHIRo, ${ }^{* *)}$ and Masami MURAMATSU*) \\ (Communicated by Toshio Kurokawa, M. J. A., Nov. 12, 1980)
}

Cytochrome P-450 in hepatic microsomes, functions as the terminal oxidase of NADPH-dependent electron transport pathway by oxidizing a wide variety of structurally unrelated compounds ranging from endogenous substrates such as steroids and fatty acids to exogenous substrates including drugs, insecticides, hydrocarbons and chemical carcinogens. This unusually broad substrate specificity has been attributed to the occurrence of multiple forms of this cytochrome (Sato and Omura, 1978; Guengerich, 1979). It has been known, in addition, that administration of a certain drug to animals induces the synthesis of a specific type of cytochrome P-450 in the liver (Sato and Omura, 1978; Guengerich, 1979). In order to investigate in detail the molecular multiplicity of cytochrome P-450 and its induction mechanism by drug administration, we have attempted to clone the complementary DNA (cDNA) sequence of cytochrome P-450 mRNA. We describe here a successful isolation and identification of the cDNA clone of rat cytochrome P- $450 \mathrm{mRNA}$ of phenobarbital-inducible type.

Materials and methods. Treatment of rats with phenobarbital and preparation of microsomes from rat livers were described previously (Negishi et al., 1976). Membrane-bound RNA was extracted from the microsomal fraction as described by Palmiter (1974). Fractionation of RNA on a poly(U) -Sepharose column and subsequently by centrifugation in a sucrose density gradient (Suzuki et al., 1972) was performed as described previously. Synthesis of double-stranded cDNA on 18S poly (A) ${ }^{+}$RNA (Maniatis et al., 1976), transformation of Escherichia coli $\chi 1776$ by pBR322-cDNA hybrid (Enea et al., 1975) and detection of the specific recombinant plasmid DNA in situ colony hybridization (Grunstein and Hogness, 1975) were conducted essentially according to the published procedures. Plasmid DNA was

*) Department of Biochemistry, Cancer Institute, Japanese Foundation for Cancer Research, Tokyo.

**) Department of Physiology, Kansai Medical University, Osaka. 
prepared as described by Taniguchi et al. (1980). Hybridizationarrested translation assay was performed according to the procedure of Paterson et al. (1977) using an in vitro translation system of wheat germ (Roberts and Paterson, 1972). Isolation of the specific mRNA by RNA-DNA hybrid formation (Taniguchi et al., 1980) was performed as described and then the mRNA was translated in the in vitro translation system. Immunological procedures for detection of cytochrome P-450 peptide synthesized in the in vitro translation system were as developed by Schimke et al. (1974). Antisera against cytochrome P-450 of phenobarbital-inducible type was prepared and its specific IgG was purified on an antigen-fixed Sepharose column as described by Negishi et al. (1976).

Results and discussion. It was previously demonstrated that cytochrome P-450 was mainly synthesized on membrane-bound polysomes (Negishi et al., 1976; Y. Fujii-Kuriyama et al., 1979). Therefore, RNA was extracted from isolated microsomes of livers of phenobarbital-treated rats and poly (A) containing mRNA was isolated by poly(U)-Sepharose column chromatography. The yield of poly (A) ${ }^{+}$ mRNA was approximately $1 \%$ of total input RNA as shown in Table I. On the basis of ${ }^{3} \mathrm{H}$-leucine incorporation in the in vitro translation system, cytochrome P-450 mRNA content was estimated to be $1.6 \%$. After fractionation of the mRNA with a 5 to $25 \%$ sucrose density gradient centrifugation into 20 portions, an aliguot of each fraction was assayed for mRNA activity in the in vitro translation system. The activity of cytochrome P-450 mRNA formed a peak around $18 \mathrm{~S}$. Three fractions around the peak of cytochrome P-450

Table I. In vitro protein synthesis by wheat germ system

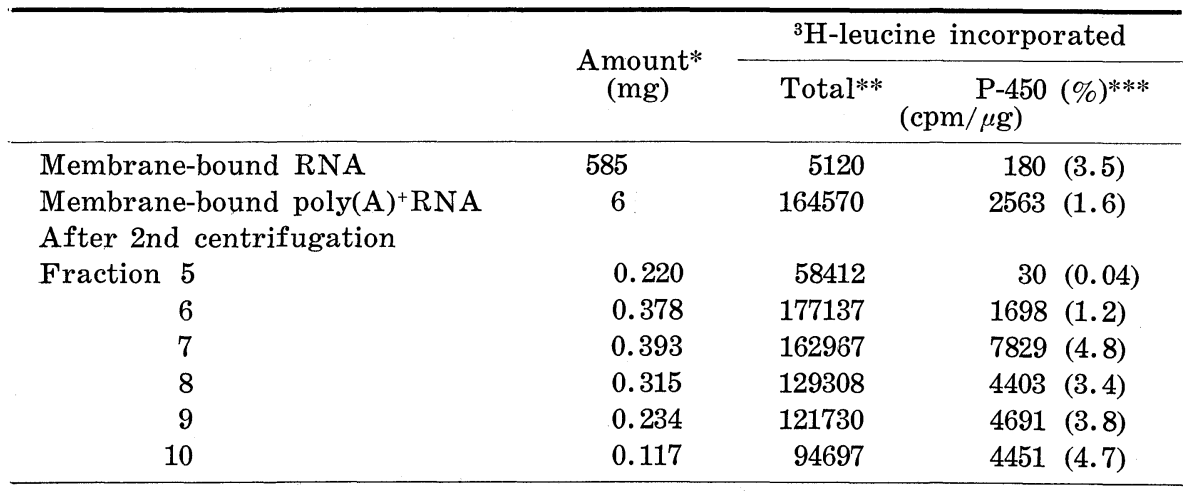

* Amount of RNA from $150 \mathrm{~g}$ rat liver. ** ${ }^{3} \mathrm{H}$-leucine incorporated into $5 \%$ trichloroacetic acid-insoluble fraction. *** ${ }^{3} \mathrm{H}$-leucine incorporated into immunoprecipitates from the total reaction mixture with anti-cytochrome P-450 antibody. 
mRNA activity was pooled and applied on a second sucrose density gradient (5-25\%) containing 70\% formamide. The mRNA activity for cytochrome P-450 was again positioned around 18S. As shown in Table I, the highest cytochrome P-450 mRNA activity was detected in fraction 7 and this fraction was used as the template for cDNA synthesis. Approximately $1.5 \mu \mathrm{g}$ of doublestranded cDNA was synthesized from $15 \mu \mathrm{g}$ of the RNA and then tailed with dCMP to about 30 nucleotides. The dC-tailed ds-cDNA was annealed with pBR322 which had been digested with PstI and tailed with dGMP and then the hybrid plasmid was used to transform $E$. coli $\chi 1776$ in the P-2 laboratory of Cancer Institute. Transformants harboring the recombinant plasmid were selected on agar plates containing tetracycline $(15 \mu \mathrm{g} / \mathrm{ml})$. The efficiency of transformation was about $1.7 \times 10^{6}$ colonies per $1 \mu \mathrm{g}$ of cDNA. For the first screening, 1000 colonies were picked up randomly and transferred to grid-meshed nitrocellulose filters in duplicate. After incubation at $37^{\circ} \mathrm{C}$ overnight, one set of nitrocellulose filters was processed for in situ colony hybridization (Grunstein and Hogness, 1975), while the other set of the filters was kept at $4^{\circ} \mathrm{C} .{ }^{32} \mathrm{P}-\mathrm{cDNA}$ which had been synthesized from the partially purified mRNA was used as probe for the colony hybridization. The strength of the hybridization signal varied among individual colonies and were classified into three categories; strong, intermediate and weak. 46 strongly positive and approximately 200 intermediately positive colonies were obtained.

From the ${ }^{3} \mathrm{H}$-leucine incorporation by the in vitro translation system, cytochrome P-450 mRNA was assumed to be one of the major species in the mRNA preparation. Therefore, we began with strongly positive colonies, to identify the recombinant plasmid containing cDNA sequence of cytochrome P-450 mRNA with the use of hybridization-arrested translation assay. Several of these strongly positive colonies were grown in liquid media and each plasmid DNA was prepared as described in Materials and methods. $2.5 \mu \mathrm{g}$ of each recombinant plasmid or pBR322 was digested with PstI, denatured at $90^{\circ} \mathrm{C}$ for $5 \mathrm{~min}$ and then hybridized with the partially purified mRNA $(2.6 \mu \mathrm{g})$ in $50 \mu \mathrm{l}$ of $80 \%$ formamide containing $10 \mathrm{mM}$ Pipes, $\mathrm{pH} 6.4$ and $0.4 \mathrm{M} \mathrm{NaCl}$ at $53^{\circ} \mathrm{C}$ for $2 \mathrm{hrs}$. Under these conditions where the RNA-DNA hybrid could be formed while DNA renaturation was negligible (Casey and Davidson, 1977), a cloned DNA having a sequence complementary to cytochrome P-450 mRNA would hybridize with that mRNA and accordingly block cell-free synthesis of cytochrome P-450 polypeptide.

The result of such a hybridization-arrested translation assay is shown in Table II. Cell-free synthesis of cytochrome P-450 which 
Table II. Hybrid-arrested translation and immunoprecipitation of the cell-free translation products

\begin{tabular}{lccc}
\hline \multirow{2}{*}{$\begin{array}{c}\text { Source of } \\
\text { arresting DNA }\end{array}$} & \multicolumn{3}{c}{ Radioactivity, cpm/45 $\mu 1$} \\
\cline { 2 - 4 } & Acid insoluble* & \multicolumn{2}{c}{$\begin{array}{c}\text { Immunoprecipitable** } \\
\text { (cyt P-450) }\end{array}$} \\
\hline \multirow{2}{*}{ 1) pBR322 } & 1.10 & \multicolumn{2}{c}{$\times 10^{-3}$} \\
I-10-9, I-10-10 & 1.96 & 2.5 & $(2.3 \%)$ \\
II-3-10 & 1.17 & 5.7 & $(2.9 \%)$ \\
II-6-3 & 1.53 & 2.8 & $(2.4 \%)$ \\
II-7-3 & 1.07 & 3.4 & $(2.2 \%)$ \\
pBR322 & 1.45 & 2.7 & $(2.5 \%)$ \\
III-3-5 & 0.98 & 4.4 & $(3.0 \%)$ \\
III-5-4, III-8-10 & 0.75 & 3.4 & $(3.4 \%)$ \\
III-9-1 & 0.99 & 0.8 & $(1.0 \%)$ \\
V-9-9 & 0.87 & 3.5 & $(3.5 \%)$ \\
\hline
\end{tabular}

* $\left[{ }^{3} \mathrm{H}\right]$ leucine incorporated into the $5 \%$ trichloroacetic acid-insoluble fraction. ** $\left[{ }^{3} \mathrm{H}\right]$ leucine incorporated into immunoprecipitates from the total reaction mixture with anti-cytochrome P-450 antibody.

accounted for 2 to $3 \%$ of the total translation product of the partially purified mRNA was inhibited only by a mixture of plasmids III-5-4 and III-8-10, while PstI-digested DNA's from other recombinant plasmids as well as pBR322 showed practically no effect. When recombinant plasmids, III-5-4 and III-8-10 were prepared separately and used for hybridization-arrested translation assay, only III-8-10 DNA inhibited the in vitro synthesis of cytochrome $\mathrm{P}-450$ polypeptide, whereas neither R $\beta$ GpBR DNA (rabbit $\beta$-globin cDNA inserted pBR322) nor III-5-4 DNA had an inhibitory effect on it (Table III). Upon heattreatment of the hybridizing reaction mixture before its addition to the in vitro translation system, the mRNA activity for cytochrome $\mathrm{P}-450$ in the reaction mixture with III-8-10 DNA recovered as shown in Table III, consistent with the notion that the inhibiting principle of III-8-10 DNA is due to RNA-DNA hybrid formation. These results were further confirmed by a positive hybridization-translation assay as described by Taniguchi et al. (1980) (data to be published elsewhere). In brief, a mixture of the partially purified cytochrome P-450 mRNA $(10 \mu \mathrm{g})$ and purified rabbit globin mRNA $(0.1 \mu \mathrm{g})$ was incubated with either III-8-10 plasmid DNA $(2.5 \mu \mathrm{g})$ or R $\beta$ GpBR DNA $(1 \mu \mathrm{g})$ or their combination under the conditions of RNA-DNA formation (Casey and Davidson, 1977). After $2 \mathrm{hrs}$ of hybridization, single-stranded plasmid DNA whose cDNA part should have been hybridized with the corresponding mRNA was strapped on a nitrocellulose filter (Nygaard and Hall, 1963) and then the hybridized 
Table III. Hybrid-arrested translation and immunoprecipitation of the cell-free translation products

\begin{tabular}{|c|c|c|c|c|}
\hline \multirow{2}{*}{\multicolumn{2}{|c|}{$\begin{array}{c}\text { Source of } \\
\text { arresting DNA }\end{array}$}} & \multicolumn{3}{|c|}{ Radioactivity, cpm/45 $\mu 1$} \\
\hline & & \multirow{2}{*}{$\frac{\text { Acid insoluble* }}{\times 10^{-5}}$} & \multicolumn{2}{|c|}{$\begin{array}{c}\text { Immunoprecipitable } \\
(\text { cyt } \mathrm{P}-450)\end{array}$} \\
\hline & & & & \\
\hline & $\mathrm{R} \beta \mathrm{G}-\mathrm{pBR}$ & 2.14 & 4.7 & $(2.2 \%)$ \\
\hline \multirow[t]{4}{*}{ 1) } & III-5-4 & 1.54 & 3.1 & $(2.0 \%)$ \\
\hline & III-5-4 (heated $* * *)$ & 1.78 & 3.8 & $(2.1 \%)$ \\
\hline & III-8-10 & 1.65 & 1.1 & $(0.6 \%)$ \\
\hline & III-8-10 (heated $* * *)$ & 1.75 & 3.0 & $(1.7 \%)$ \\
\hline \multirow[t]{4}{*}{ 2) } & III-5-4 & 1.73 & 3.2 & $(1.8 \%)$ \\
\hline & III-5-4 (heated***) & 1.69 & 3.1 & $(1.8 \%)$ \\
\hline & III-8-10 & 1.45 & 1.0 & $(0.7 \%)$ \\
\hline & III-8-10 (heated $* * *)$ & 1.52 & 3.0 & $(2.0 \%)$ \\
\hline
\end{tabular}

* $\left[{ }^{3} \mathrm{H}\right]$ leucine incorporated into the $5 \%$ trichloroacetic acid-insoluble fraction. ** $\left[{ }^{3} \mathrm{H}\right]$ leucine incorporated into immunoprecipitates from the total reaction mixture with anti-cytochrome $\mathrm{P}-450$ antibody. $* * *$ After DNA-RNA hybrid formation (for details, see the text), one half of the reaction mixture was heated at $90^{\circ} \mathrm{C}$ for 3 min to dissociate RNA-DNA hybrid and then RNA was precipitated with ethanol prior to translation by the cell-free translation system.

mRNA was eluted from the filter for translation by the cell-free system. mRNA which was isolated from the mRNA mixture with III8-10 DNA synthesized mainly a single protein with an apparent molecular weight of 50,000 dalton which corresponded to that obtained with cytochrome P-450 and was immunoprecipitable with anti$\mathrm{P}-450$ antibody, while mRNA isolated with $\mathrm{R} \beta \mathrm{GpBR}$ gave a main translation product of $\beta$-globin. Combination of the two plasmid DNA gave the mRNA activity showing an enriched synthesis of both the proteins as expected. Taken together, we conclude that III-8-10 plasmid DNA contains the inserted DNA sequence complementary to cytochrome P-450 mRNA. The recombinant plasmid which we have constructed will not only be useful for elucidating the hitherto unknown structure of cytochrome P-450 mRNA but also provide an important means for further work on the structure, diversity and regulation of the cytochrome P-450 gene system.

Acknowledgement. This work was supported in part by grants from the Ministry of Education, Science and Culture of Japan.

\section{References}

Casey, J., and Davidson, N. (1977): Nucleic Acids Res., 4, 1539-1552.

Enea, V., Vovis, G. F., and Zinder, N. D. (1975) : J. Mol. Biol., 96, 495-509. 
Fujii-Kuriyama, Y., Negishi, M., Mikawa, R., and Tashiro, Y. (1979): J. Cell Biol., 81, 510-519.

Grunstein, M., and Hogness, D. S. (1975) : Proc. Natl. Acad. Sci. USA, 72, 39613965.

Guengerich, P. F. (1979) : Pharmac. Ther., 6, 99-121.

Harpold, M. M., Dobner, P. R., Evans, R. M., and Bancroft, F. C. (1978) : Nucleic Acids Res., 5, 2039-2053.

Lindberg, U., and Persson, T. (1972) : Eur. J. Biochem., 31, 246-254.

Maniatis, T., Sim, G. K., Efstratiadis, A., and Kafatos, F. C. (1976) : Cell, 8, 163-182.

Negishi, M., Fujii-Kuriyama, Y., Tashiro, Y., Imai, Y. (1976) : Biochem. Biophys. Res. Commun., 71, 1153-1160.

Nygaard, A. P., and Hall, B. D. (1963) : Biochem. Biophys. Res. Commun., 12, 98-104.

Palmiter, R. D. (1974) : Biochemistry, 17, 3606-3615.

Paterson, B. M., Roberts, B. E., and Kuff, E. L. (1977) : Proc. Natl. Acad. Sci. USA, 74, 4370-4374.

Roberts, B. E., and Paterson, B. M. (1972): Proc. Natl. Acad. Sci. USA, 70, 2330-2334.

Sato, R., and Omura, T. (1978) : Cytochrome p-450. Academic Press, New York and London.

Schimke, R. T., Rhoads, R. E., and Mcknight, G. S. (1974) : Method in Enzymology, 30, 694-701.

Suzuki, Y., Gage, L., and Brown, D. D. (1972) : J. Mol. Biol., 70, 637-649.

Taniguchi, T., Fujii-Kuriyama, Y., and Muramatsu, M. (1980) : Proc. Natl. Acad. Sci. USA, 77, 4003-4006. 